J. AMER. SOC. HoRT. SCI. 117(5):802-807. 1992.

\title{
Cucumber Cultivars Differ in Their Response to Chilling Temperatures
}

\author{
Roberto M. Cabrera and Mikal E. Saltveit, Jr. \\ Department of Vegetable Crops, Mann Laboratory, University of California, Davis, CA 95616 \\ Ken Owens \\ Peto Seed Research Center, Woodland, CA 95695 \\ Additional index words. conductivity, Cucumis sativus, ethylene forming enzyme activity, exudate, overall quality
}

\begin{abstract}
The physiological responses associated with chilling of horticulturally mature cucumber (Cucumis sativus L.) fruit were examined using 13 lines that differ in chilling sensitivity. The low correlation coefficient between pitting and decay suggested that these two early manifestations of chilling injury are not significantly related. Likewise, fruit pitting and decay were not highly correlated with the tolerance of seedlings to chilling, suggesting that fruit and seedlings of the same line may have dissimilar sensitivity to chilling temperatures. Exudates from fruit cut in half transversely were collected on filter paper. The amount of exudate showed a significant correlation with pitting, decay, and percent ion leakage after 10 days of chilling. The fresh and dry weight of the exudates from fruit kept for 8 days at 12.5C ranged from 141- to 346-mg fresh weight and from 15 to 47-mg dry weight, respectively. Cucumber lines that were more sensitive to chilling had watery exudate, as indicated by their lower dry weight and percent solids. The conductivity of exudates from sensitive lines was higher $(60 \mu$ siemen/cm) than from chilling resistant lines (30 $\mu$ siemen/cm). Chilling-induced ethylene production was higher in sensitive than in resistant lines, and chilling caused a greater loss of ethylene forming enzyme activity in resistant lines than from chilling sensitive lines.
\end{abstract}

Chilling injury is an economically important postharvest problem that reduces the overall quality and marketability of many harvested fruits and vegetables indigenous to the tropics and subtropics (Couey, 1982; Lyons, 1973; Saltveit and Morris, 1990). Sensitivity to chilling injury varies among species of Passiflora (Patterson et al., 1976) and Lycopersicon (Paull, 1981), among cultivars of avocados (Persea americana Mill.; Hatton et al., 1965), cucumbers (Jasim and Marr, 1989), papayas (Carica papaya L. ; Chen and Paull, 1986), tomatoes (Lycopersicon esculentum Mill.; Burgis, 1970; King and Ludford, 1983), and watermelons (Citrullus lunatus L.; Risse et al., 1990).

Chilled cucumbers exhibit reduced shelf life characterized by accelerated water loss, surface pitting, and increased susceptibility to disease (Eaks and Morris, 1956, 1957; Ryall and Lipton, 1979). A significant increase in solute leakage was observed from mesocarp tissue excised from cucumbers exposed to chilling temperatures (Cabrera and Saltveit, 1990; Tatsumi and Murata, 1978; Tatsumi et al., 1981). Jasim and Marr (1989) observed that leakage of $\mathrm{Mg}+$ and $\mathrm{K}+$ was greater in sensitive than in resistant cultivars of cucumbers after 20 days at 4.4C. Surface pitting developed on 'Poinsett 76' fruit that were exposed to $2.5 \mathrm{C}$ for $>3$ days (Cabrera and Saltveit, 1990). Similar results were observed by Jasim and Marr (1989) in resistant cultivars, (e.g., 'Dasher II' and 'Universal'), but not in sensitive cultivars, (e.g., 'Monarch' and 'Sweet Slice'), which showed slight pitting after the fruit were exposed to $4.4 \mathrm{C}$ for 3 days.

The objectives of this present study were to characterize the physiological responses of fruit from various cucumber cultivars to chilling temperatures, and to correlate these changes with subjective evaluations of chilling injury in those fruit.

Received for publication 22 July 1991. Accepted for publication 27 Apr. 1992. We express our appreciation to Peto Seed Research Center, Woodland, Calif., for providing cucumber fruit. The cost of publishing this paper was defrayed in part by the payment of page charges. Under postal regulations, this paper therefore must be hereby marked advertisement solcly to indicate this fact.
Materials and Methods

Plant material and data analyses. Thirteen lines of cucumber plants with known differences in tolerance to cold temperatures were grown at the Peto Seed Demonstration farm in Woodland, Calif. Fruit from nonchilled greenhouse-grown plants were hand harvested at horticultural maturity and handled as previously described (Cabrera and Saltveit, 1990). Uniform fruit free of visual defects were blocked for size and shape among treatments. Fruit were not washed. Fruit in each replicate were placed in shallow plastic trays that were covered loosely with plastic film to minimize water loss.

Depending on the number of fruit available at each harvest, from three to five fruit were used as replicates. Each experiment was repeated with similar results. Data were subjected to an analysis of variance and, if significant differences were detected $(P=0.05)$, LSD values were calculated at $P=0.05$ and used to separate treatment means. The coefficient of linear correlation ( $r$ ) was calculated between some sets of data.

Pitting and decay. The severity of pitting and decay was determined subjectively on an 8-point Hedonic scale as previously described (Cabrera and Saltveit, 1990). The scoring system was $0=$ no pitting or decay $(0 \%$ of the surface was pitted or decayed $), 2=$ slight $(1 \%$ to $5 \%), 4=$ moderate $(6 \%$ to $15 \%), 6=$ severe $(16 \%$ to $75 \%)$, and $8=$ very severe $(>75 \%)$. Measurements were made from 0 to 6 days after transfer from the chilling temperature to $20 \mathrm{C}$.

Overall quality. The overall quality, based on the general appearance of the fruit, was measured subjectively on an 8point Hedonic scale where $0=$ poor (extremely defective), 2 = fair (defective), $4=$ good (moderately defective), $6=$ very good (slightly defective), $8=$ excellent (not defective). Fruit were scored for quality before chilling and after 8 days at $2.5 \mathrm{C}$ plus an additional 6 days at $20 \mathrm{C}$.

Resistance of seedlings. Subjective evaluation of the viability of field- and greenhouse-grown cucumber plants to chilling temperatures were used to rank cultivars on a scale of $1=$ most susceptible to $10=$ most resistant (observations by K. Owens).

Abbreviation: EFE, ethylene forming enzyme. 
Yellowing. Yellowing was scored on an 8-point Hedonic scale, where $0=$ green (no trace of yellow), $2=$ slight yellow $(1 \%$ to $25 \%$ yellow), $4=$ moderately yellow ( $26 \%$ to $50 \%$ yellow), $6=$ mostly yellow $(51 \%$ to $74 \%$ yellow), $8=$ yellow $(75 \%$ to $100 \%$ yellow). Initial color was determined before chilling at 2.5C and then at 2 and 4 days after transfer to 20C.

Firmness. Firmness of the mesocarp was determined at two opposite locations near the peeled middle section of the fruit with a Univ. of California firmness tester (Western Industrial Supply, San Francisco) equipped with a 9-mm probe.

Measurement of ion leakage. Ion leakage was determined as described by Cabrera and Saltveit (1990). Epidermal mesocarp disks were excised with a stainless steel cork borer from the central region of each fruit, trimmed of seed cavity tissue to 4$\mathrm{mm}$ thickness with a stainless steel razor blade, and washed for $1 \mathrm{~min}$ in two changes of $20 \mathrm{ml}$ each of deionized water. Two 4-mm thick $\times 9$-mm diameter disks, weighing a total of $\approx 0.7$ $\mathrm{g}$, were placed in 50-ml centrifuge tubes containing $15 \mathrm{ml}$ of $0.3 \mathrm{M}$ mannitol, and the tubes were weighed. The tubes were shaken at 100 cycles per minute before and between readings. Conductivity was measured after 0.5 and $1.5 \mathrm{~h}$ with an Extech conductivity meter Model 480 (Extech, Waltham, Mass.). The tubes containing the tissue were boiled for $5 \mathrm{~min}$, cooled to room temperature, made to their original weight with deionized water, and their conductivity was determined after $30 \mathrm{~min}$ of shaking. Ion leakage during 0.5 to $1.5 \mathrm{~h}$ is expressed as a percentage of the total conductivity after boiling.

Exudates. Fruit were cut in half transversely at a midpoint between blossom and stem ends, and exudates were collected from the stem end half as follows. The cut end of each of three fruit was put on a weighed 9-cm diameter Whatman \#1 filter paper positioned in the center of a weighed $30 \times 30 \mathrm{~cm}$ sheet of plastic cling film. The initial weights of the filter paper and plastic film were determined after drying them over $\mathrm{CaCl}$, for $24 \mathrm{~h}$ in a desiccator at room temperature. After the exudates had been absorbed by the filter paper from the cut surface of the fruit for $60 \mathrm{sec}$, the fruit was removed and the filter paper was immediately wrapped in the plastic film to prevent moisture loss during weighing. The filter paper, without the plastic film, was dried over $\mathrm{CaCl}$, in a desiccator for $24 \mathrm{~h}$ (with the first 4 $\mathrm{h}$ in-vacua) before the dried weight was measured. The weight of the solids was the dry weight minus the initial weight of the filter paper. A measure of the relative ion content among the exudates was determined by measuring the conductivity of 50 $\mathrm{ml}$ of deionized water in which the dried filter paper was incubated for $1 \mathrm{~h}$ with shaking at 100 cycles per min. The conductivity was measured with the Extech conductivity meter.

Ethylene and $\mathrm{CO}_{2}$ production. The rates of $\mathrm{C}_{2} \mathrm{H}_{4}$ and $\mathrm{CO}_{2}$ evolution from each of three fruit replicates kept at $2.5 \mathrm{C}$ were calculated from an analysis of 1-ml samples taken from the headspace gas that accumulated during $1 \mathrm{~h}$ in 4-liter glass jars (Cabrera and Saltveit, 1990; Saltveit and McFeeters, 1980).

EFE activity. Ethylene forming enzyme (EFE) activity was analyzed in washed epidermal mesocarp disks that were excised from the middle of fruit with a stainless steel cork borer (Cabrera and Saltveit, 1990). The disks were trimmed of seed cavity tissue to 4-mm thickness with a stainless steel razor blade and washed for $1 \mathrm{~min}$ in two changes of 20-ml deionized water. Excess moisture was removed with paper towels. Two 4-mm thick $\times 9$-mm diameter disks, weighing a total of $\approx 0.7 \mathrm{~g}$, were placed in $16 \times 100-\mathrm{mm}$ glass culture tubes with $3 \mathrm{ml}$ of $2 \mathrm{~mm}$ 1-aminocyclopropane-1-carboxylic acid (ACC) or deionized water and vacuum infiltrated for $30 \mathrm{sec}$. Disks were then blotted dry and sealed with a serum stopper in a $16 \times 100$-mm culture tube. After $1 \mathrm{~h}$ of incubation, a l-ml sample of headspace gas was withdrawn and injected in a Carle (Loveland, Colo.) gas chromatograph equipped with a flame ionization detected to quantitate the $\mathrm{C}_{2} \mathrm{H}_{4}$ produced. EFE activity was calculated as the difference between $\mathrm{C}_{2} \mathrm{H}_{4}$ produced with and without ACC.

\section{Results}

Pitting. The severity of pitting depended on cultivar, ranging from 0.0 to 7.7 in fruit chilled for 8 days at $2.5 \mathrm{C}$ and kept for an additional 6 days at 20C (Table 1). 'Marketmore 76F' developed no pits, while 'Line 159' and 'Dasher II' developed a few pits. The most pitted fruit were 'Poinsett 76', followed by 'MDR I' and 'Poinsett 110' or 'Eurol $\times$ Sampson', but the differences among the most pitted fruit were nonsignificant.

After 8 days of chilling at $2.5 \mathrm{C}$, but before being kept at 20C, no pitting was observed on 'Marketmore 76F', 'Dasher II', 'Poinsett 83', and 'Line 159'. In contrast, 'Poinsett 76', 'MDR I', and 'Maram' had scores of 2 (data not shown). Slight pitting $(<2)$ was observed on 'Poinsett 110', 'Navajo F1', ' $\mathrm{D}_{2} \mathrm{~F}_{5} \mathrm{Mo}$ ', 'Eurol $\times$ Sampson', and 'PSX 34885'. 'Marketmore $76 \mathrm{~F}$ ' appeared to be the most resistant to pitting, whereas 'Poinsett 76' appeared to be the most susceptible.

Decay. 'Dasher II', 'Marketmore 76F', 'Poinsett 83', and 'PSX 34885' fruit did not show any decay when kept for 8 days at $2.5 \mathrm{C}$ followed by 6 days at 20C (Table 1). More sensitive lines, e.g., 'Poinsett 110' and 'Eurol $\times$ Sampson' had decay scores of 5.0 and 3.0, respectively, after 6 days at 20C.

Overall quality. There were no significant differences in initial quality among the cultivars (Table 1). After 8 days of chilling at $2.5 \mathrm{C}$ and an additional 6 days at 20C, a $90 \%$ decline in quality from 6.7 to 0.7 was observed in 'Eurol $\times$ Sampson' fruit. In contrast, only a slight reduction in quality was observed in 'Marketmore 76F', 'Poinsett 83', 'PSX 34885', and 'Dasher II'. Apart from 'Eurol $\times$ Sampson' and 'Mara', which had very poor quality after chilling (Table 1) and were very yellow after chilling (Table 2), the correlation between overall quality after 8 days of chilling plus 6 days at 20C (Table 1) and color after 8 days of chilling plus 4 days at 20C (Table 2) for the other cultivars was poor $(r=-0.22)$.

Resistance of seedlings. The resistance of seedlings to chilling ranged from a susceptible 2.5 for 'Navajo F1', 'Poinsett 76', and 'Poinsett 110 ', to a resistant 7.0 for ' $\mathrm{D}_{2} \mathrm{~F}_{5} \mathrm{Mo}$ ', 'Marketmore 76F', and 'PSX 34885' (Table 1).

Yellowing. After 8 days of chilling plus 2 days at 20C, the yellowing scores ranged from 1.7 to 3.0 and increased to 2.3 to 6.0 after an additional 2 days at 20C (Table 2). No yellowing was observed in 'Marketmore 76F' and 'PSX 34885' after 8 days at $2.5 \mathrm{C}$ and up to 2 days at 20C. Moreover, these two lines plus ' $\mathrm{D}_{2} \mathrm{~F}_{5} \mathrm{Mo}$ ' and 'MDR I' showed only moderate yellowing after 4 days at 20C. In contrast, more severe yellowing occurred in 'Eurol $\times$ Sampson' and 'Maram' after 2 or 4 days at 20C. The initial low yellowing score of 'Navajo F1' made its moderate score after 4 days the largest increase in yellowing (4.3-fold).

Firmness. While 'Eurol $\times$ Sampson' and 'Line 159' were softer after storage at $2.5 \mathrm{C}$ than when stored at $12.5 \mathrm{C}$, most cultivars were either similar in firmness (three cultivars) or firmer (eight cultivars) after storage at 2.5C (Table 3). The greater firmness of fruit stored at 2.5 vs. $12.5 \mathrm{C}$ ranged from $\approx 11 \%$ ( $9 \%$ to $13 \%$ in five cultivars), to $\approx 27 \%$ ( $20 \%$ to $32 \%$ in two cultivars). The correlation between firmness at 12.5 and $2.5 \mathrm{C}$ was only 0.46 , while the correlation between firmness at $12.5 \mathrm{C}$ 
Table 4. Comparison of the percent total ion leakage from various lines of cucumbers. Disks were excised from fruit that were chilled for 6 or 10 days at $2.5 \mathrm{C}$ and then kept 1 day at $20 \mathrm{C}$.

\begin{tabular}{|c|c|c|c|c|c|}
\hline \multirow[b]{2}{*}{ Cultivar } & \multicolumn{4}{|c|}{ Ion leakage $(\%)$} & \multirow[b]{2}{*}{ Difference $(\%$} \\
\hline & 6 days a & $2.5 \mathrm{C}$ & 10 days & at $2.5 \mathrm{C}$ & \\
\hline $\mathrm{D}_{2} \mathrm{~F}_{5} \mathrm{Mo}$ & 5.9 & $\mathrm{~cd}^{\mathrm{z}}$ & 6.2 & $c$ & 5 \\
\hline Dasher II & 7.6 & $\mathrm{~b}$ & 8.4 & $\mathrm{bc}$ & 11 \\
\hline Eurol $\times$ Sampson & 7.7 & $\mathrm{~b}$ & 14.3 & $\mathrm{a}$ & 86 \\
\hline Line 159 & 11.0 & $\mathrm{a}$ & 11.4 & $a b$ & 4 \\
\hline Maram & 5.9 & $\mathrm{~cd}$ & 7.9 & $\mathrm{bc}$ & 34 \\
\hline Marketmore $76 \mathrm{~F}$ & 5.4 & cde & 7.5 & $\mathrm{bc}$ & 39 \\
\hline MDR I & 4.5 & $\mathrm{e}$ & 13.7 & a & 204 \\
\hline Navajo F1 & 4.6 & de & 5.5 & $c$ & 20 \\
\hline Poinsett 76 & 6.8 & $\mathrm{~b}$ & 15.0 & $\mathrm{a}$ & 120 \\
\hline Poinsett 83 & 6.0 & c & 9.1 & $b c$ & 52 \\
\hline Poinsett 110 & 5.6 & cde & 6.5 & $\mathrm{c}$ & 16 \\
\hline PSX 34885 & 5.8 & cde & 7.8 & $b c$ & 35 \\
\hline Rawa & 7.7 & $\mathrm{~b}$ & 6.5 & $\mathrm{c}$ & -0.2 \\
\hline
\end{tabular}

${ }^{2}$ Means separation within columns are by LSD, $P=0.05$.

Six lines were selected to characterize the exudate from chilled fruit. The amounts of fresh exudate from the chilled fruit were more poorly correlated with dry weight $(r=-0.15)$ than in nonchilled fruit, but it was again highly correlated with conductivity $(r=0.98)$. The correlation between dry exudate weight and percent solids $(r=0.88)$ was much higher than in nonchilled fruit. With the exception of 'Poinsett 76', which had the lowest percent solids and the highest conductivity, the correlation between percent solids and conductivity was again very poor $(r=0.06)$. The correlation between the conductivity of exudates from chilled and nonchilled fruit was also very poor $(r=0.01)$.

The two cultivars with low pitting scores and higher overall quality, e.g., 'Dasher II' and 'Marketmore 76F' (Table 1), produced the least fresh exudate from chilled fruit, and the exudate had the lowest conductivity. The two cultivars with the highest pitting scores, e.g., 'MDR I' and 'Poinsett 76', produced the most fresh exudate from chilled fruit, and the exudate had the highest conductivity. The amount of the exudate was highly correlated with pitting $(r=0.85)$, decay $(r=0.85)$, and percent ion leakage after 10 days of chilling $(r=0.92)$. In contrast, there were much lower correlations between exudate and seed- ling tolerance to chilling $(r=0.44)$, or percent ion leakage in fruit chilled for a shorter period $(r=0.27$, after 6 days of chilling).

Respiration and ethylene production. Production of $\mathrm{CO}_{2}$ ranged from 4.8 to $8.7 \mathrm{mg}(\mathrm{kg} \cdot \mathrm{h})^{-1}$ from fruit of seven selected lines kept for 3 days at $2.5 \mathrm{C}$ and from 4.3 to $7.0 \mathrm{mg}(\mathrm{kg} \cdot \mathrm{h})^{-1}$ after 6 days at $2.5 \mathrm{C}$ (Table 6). 'Marketmore 76F' had the highest respiration rate after 3 days of chilling, while 'Eurol $\times$ Sampson' had the highest after 6 days. 'Poinsett 83' and 'PSX 34885' had the lowest respiration rates after 3 days at $2.5 \mathrm{C}$, while 'PSX $34885^{\prime}$ had the lowest rate after 6 days. Some lines showed slight increases in respiration from 3 to 6 days of chilling, e.g., 'Dasher II', 'Poinsett 83', and 'Eurol $\times$ Sampson', whereas slight decreases were observed in 'Marketmore 76F', 'MDR I', and 'PSX 34885'. No significant increase or decrease in $\mathrm{CO}$ production was observed in 'Poinsett 76', which agreed with our previous observations (Cabrera and Saltveit, 1990).

Ethylene production in seven lines ranged from 5.5 to 22.3 nl $\mathrm{C}_{2} \mathrm{H}_{4}(\mathrm{~kg} \cdot \mathrm{h})^{-1}$ and 2.2 to $14.3 \mathrm{nl} \mathrm{C}_{2} \mathrm{H}_{4}(\mathrm{~kg} \cdot \mathrm{h})^{-1}$ after 3 and 6 days, respectively, of storage at $2.5 \mathrm{C}$ (Table 6). All lines showed a $23 \%$ to $71 \%$ decrease in $\mathrm{C}_{2} \mathrm{H}_{4}$ production after 3 to 6 days of storage at $2.5 \mathrm{C}$.

The correlation between $\mathrm{CO}_{2}$ production on day 3 and 6 was much smaller $(r=0.46)$ than between $\mathrm{C}_{2} \mathrm{H}_{4}$ production on day 3 and $6(r=0.74)$. The correlation between $\mathrm{CO}_{2}$ and $\mathrm{C}_{2} \mathrm{H}_{4}$ production on day $6(r=0.38)$ was larger than on day $3(\mathrm{r}=$ 0.11 ), although both indicate a poor relationship. The percent change in $\mathrm{CO}_{2}$ production was slightly correlated with the percent change in $\mathrm{C}_{2} \mathrm{H}_{4}$ production $(r=0.57)$.

EFE activity. EFE activity was measured in tissue from three cultivars that were selected on the basis of their development of pitting, decay, and percent ion leakage. Tissue from these cultivars showed a decline in EFE activity upon chilling (Table 7). For both chilled and nonchilled fruit, EFE activity was highest in 'Eurol $\times$ Sampson' and lowest in 'MDR I'.

\section{Discussion}

The severity of chilling-induced damage varied among cucumber cultivars. Pitting and decay are two visual symptoms of chilling injury in cucumber fruit (Eaks and Morris, 1957) that are interrelated in the cultivar 'Poinsett 76' (Cabrera and Saltveit, 1990). However, the low correlation between pitting and

Table 5. Fresh and dry exudate weight, percent solids, and conductivity of various lines of nonchilled and chilled cucumber fruit kept for eight days at $12.5 \mathrm{C}$ (nonchilled) or 10 days at $2.5 \mathrm{C}$ (chilled). Exudates were collected and analyzed at 20C.

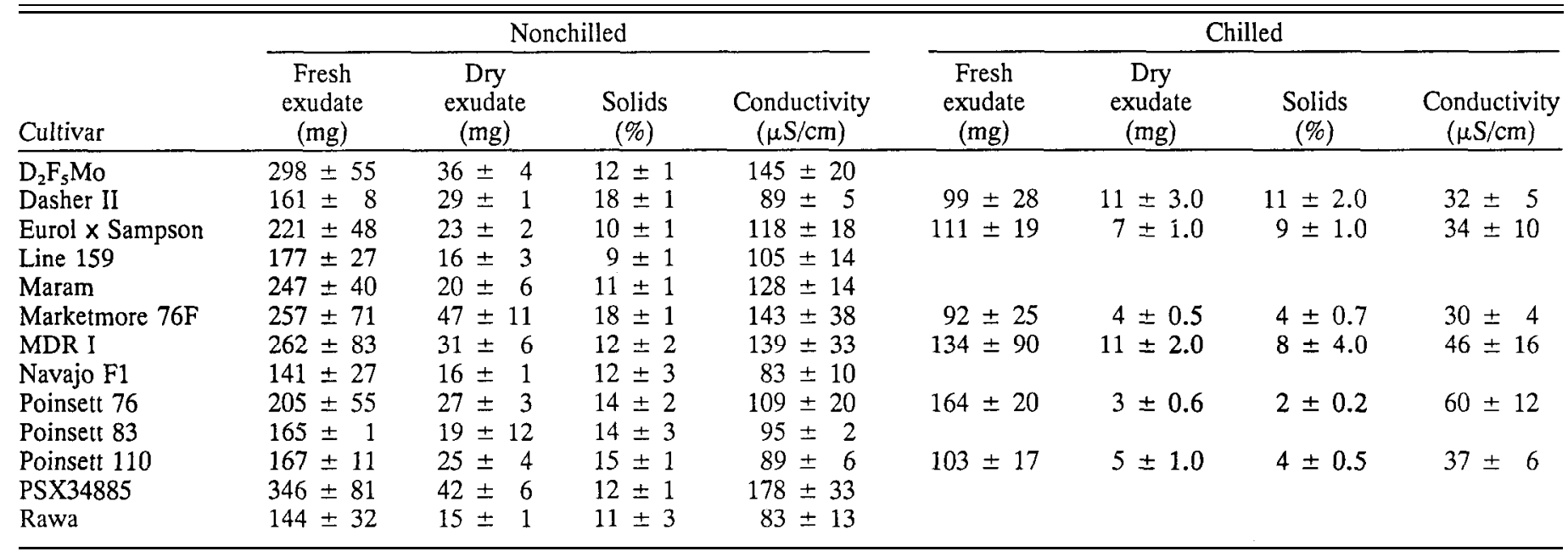


ethylene production was consistent with our previous findings with chilled 'Poinsett 76' cucumber fruit (Cabrera and Saltveit, 1990).

Conclusion. Fruit from various cucumber cultivars exhibited significant differences in sensitivity to chilling as shown by various subjective and objective measurements. The variability in correlations among the measurements of chilling sensitivity within and among these cucumber cultivars indicates that their physiological and horticultural response to chilling is complex. Breeding for chilling resistance and devising postharvest strategies to reduce chilling injury must, therefore, adopt several approaches to encompass the diversity of these responses.

\section{Literature Cited}

Burgis, D.S. 1970. Fruit chilling and ripening studies for evaluation of breeding lines of fresh market tomatoes. Proc. Florida State Hort. Soc. 83:135-137.

Cabrera, R.M. and M.E. Saltveit. 1990. Physiological response to chilling temperatures of intermittently warmed cucumber fruit. J. Amer. Soc. Hort. Sci. 115:256-261.

Chen, N. and R.E. Paull. 1986. Development and prevention of chilling injury in papaya fruit. J. Amer. Soc. Hort. Sci. 111:639-643.

Couey, H.M. 1982. Chilling injury of crops of tropical and subtropical origin. HortScience 17:162-165.

Eaks, I.L. and L.L. Morris. 1956. Respiration of cucumber fruits associated with physiological injury at chilling temperatures. Plant Physiol. 31:308-314.

Eaks, I.L. and L.L. Morris. 1957. Deterioration of cucumbers at chilling and nonchilling temperatures. Proc. Amer. Soc. Hort. Sci. 69:388399.

Field, R.J. 1990. Influence of chilling stress on ethylene production, p. 235-253. In: C.Y. Wang (ed.). Chilling injury of horticultural Crops. CRC Press, Boca Raton, Fla.

Hatton, T.T., Jr., W.F. Reeder, and C.W. Campbell. 1965. Ripening and storage of Florida avocados, U.S. Dept. Agr. Mktg. Res. Rpt. 697.

Jasim, A.M. and C.W. Marr. 1989. Fruit firmness, total soluble solids, water content, cuticular waxes and fatty acid composition of cuc- umber cultivars during chilling temperature storage. PhD Diss., Dept. Hort., Kansas State Univ., p 89.

King, M.M., and P.M. Ludford. 1983. Chilling injury and electrolyte leakage in fruit of different tomato cultivars. J. Amer. Soc. Hort. Sci. 108:74-77.

Lyons, J.M. 1973. Chilling injury in plants. Annu. Rev. Plant Physiol. 24:445-466.

Murata, T. and Y. Tatsumi. 1979. Ion leakage in chilled plant tissues, p. 141-151. In: J.M. Lyons, D. Graham, and J.K. Raison (eds.). Low temperature stress in crop plants. Academic, New York.

Patterson, B.D., T. Murata, and D. Graham. 1976. Electrolyte leakage induced by chilling in Pussiflora species tolerant to different climates. Austral. J. Plant Physiol. 3:435-442.

Paull, R.E. 1981. Temperature-induced leakage from chilling-sensitive and chilling-resistant plants. Plant Physiol. 68:149-153.

Risse, L.A., J.K. Brecht, S.A. Sargent, S.J. Locascio, J.M. Crall, G.W. Elmstrom, and D.N. Maynard. 1990. Storage characteristics of small watermelon cultivars. J. Amer. Soc. Hort. Sci. 115:440443.

Ryall, A.L. and W.J. Lipton. 1979. Handling, transportation and storage of fruits and vegetables. AVI, Westport, Conn., p. 28-29.

Saltveit, M.E., Jr., and R.M. Cabrera. 1987. Tomato fruit temperature before chilling influences ripening after chilling. HortScience 22:452454

Saltveit, M.E., Jr., and R.F. McFeeters. 1980. Polygalacturonase activity and ethylene synthesis during cucumber fruit development and maturation. Plant Physiol. 66:1019-1023.

Saltveit, M.E., Jr., and L.L. Morris. 1990. Overview on chilling injury of horticultural crops, p 1-14. In: C.Y. Wang (ed.). Chilling injury of horticultural crops. CRC Press, Boca Raton, Fla.

Tatsumi, Y., M. Iwamoto, and T. Murata. 1981. Electrolyte leakage from discs of Cucurbitaceae fruit associated with chilling injury. $\mathrm{J}$. Jpn. Hort. Sci. 50:114-119.

Tatsumi, Y., K. Maeda, and T. Murata. 1987. Morphological changes in cucumber fruit surfaces associated with chilling injury. J. Jpn. Soc. Hort. Sci. 56:187-192.

Tatsumi, Y. and T. Murata. 1978. Studies on chilling injury of fruit and vegetables. I. Chilling injury of cucumber fruits with special reference to permeability of the tissue membrane. J. Jpn. Soc. Hort. Sci. 47:105-110. 